American Journal of Infectious Diseases 5 (4): 288-293, 2009

ISSN 1553-6203

(C) 2009 Science Publications

\title{
Dengue during Pregnancy: A Study of Thirteen Cases
}

\author{
${ }^{1}$ Christiane Fernandes Alvarenga, ${ }^{2}$ Vânia Glória Silami, ${ }^{3}$ Patrícia Brasil, \\ ${ }^{1}$ Maria Elizabeth Herdy Boechat, ${ }^{3}$ Janice Coelho and ${ }^{4}$ Rita Maria Ribeiro Nogueira \\ ${ }^{1}$ Health Surveillance Services of the Azevedo Lima Hospital, ZIP Code: 24130-616, Rio de Janeiro, 30, \\ Teixeira de Freitas Street, Fonseca, Niterói, Rio de Janeiro, Brazil \\ ${ }^{2}$ Department of Pathology, Universitary Hospital Antonio Pedro, ZIP Code: 24033-900, Rio de Janeiro, \\ 303, Marquês de Paraná Street, Centro, Niterói, Rio de Janeiro, Brazil \\ ${ }^{3}$ Institute of Clinical Research Evandro Chagas/Fiocruz, ZIP Code: 21040-900, 4365, Avenida Brasil, \\ Manguinhos, Rio de Janeiro, Brazil \\ ${ }^{4}$ Flavirus Laboratory of the Oswaldo Cruz Institute /Fiocruz, ZIP Code: 21040-360, Rio de Janeiro, \\ Brazil, 4365, Avenida Brasil, Manguinhos, Rio de Janeiro, Brazil
}

\begin{abstract}
Problem statement: The principal aim was to evaluate the effects of dengue virus infection by dengue during pregnancy and analyze the histopathology of the placenta. Approach: A retrospective study was conducted with 13 pregnant women with dengue confirmed in the period from January-December 2002, during a widespread dengue type 3 epidemic in Rio de Janeiro. Maternal and newborn data were collected from patient files and medical records during hospitalization for research for identification of dengue IgM antibodies (PanBio, Australia). Virus isolation was performed on all fatal cases and anathomopathological studies and immunohistochemistry of the placenta were carried out in three cases. Results: Among the 13 women, $11(84,6 \%)$ were infected in the third quarter of pregnancy, $6(54,5 \%)$ of which resulting in premature birth and 4 cases $(30,7 \%)$ were classified as DHF, causing 2 deaths. Intense abdominal pain afflicted 6 patients $(46,2 \%)$ and 5 newborns presented low weight, however appropriate for the gestacional age. Conclusion: Dengue virus infection in pregnancy increases premature birth risk, especially if the infection occurs in the last quarter of pregnancy.
\end{abstract}

Key words: Dengue, pregnancy, premature birth, ARDS, placenta

\section{INTRODUCTION}

Within the last decade, there has been an increase or emergence of several human infections and the surge of others that had previously been under control. The major factors are related to modern man s impact on the environment, such as the demographic explosion ${ }^{[1,2]}$.

In the literature, there are controversial reports addressing the effects of dengue in pregnant women, the fetus and the newborn. There have been descriptions of thrombocytopenia, liver insufficiency and hemorrhagic complications after childbirth in pregnant women, evidencing the importance of diagnosis distinction from the diseases that are common to pregnancy, such as the HELLP Syndrome ${ }^{[3-6]}$.

Some authors have illustrated that despite the occurrence of the dengue viral infection in pregnant women, there are no indications of intra-uterus infection, congenital disease or severe dengue events during the neonatal period and during the first year of life ${ }^{[7,8]}$. However, in the last 10 years there have been reports of vertical transmission with severe consequences to both the fetus and the newborn.

Tan et $a l .^{[9]}$ in a study of prospective cohort, described the vertical transmission incidence rate as $1,6 \%$. Vertical transmission reports describe the following findings in the newborn: tachypnea, feeding intolerance and hypoglycemia associated to fever, petechie, hepatomegaly, thrombocytopenia ${ }^{[10,11]}$, skin rash $^{[12]}$, pleural effusion ${ }^{[13]}$, prematurity and hemorrhagic complications leading to the dengue-shock syndrome $^{[3-5,14]}$.

During the summer of 2002, Rio de Janeiro had a large epidemic of dengue fever; 288,245 cases were reported. This explosive epidemic of DENV-3 was the most severe dengue epidemic reported in Brazil ${ }^{[15]}$. In

Corresponding Author: Christiane Fernandes Alvarenga, R. Luiz Leopoldo Fernandes Pinheiro, 551/809, ZIP Code: 24030-121, Niterói, Rio de Janeiro, Brazil Tel: 552126218824 
this manuscript, we describe 13 serology confirmed cases of dengue in pregnant women, together with the fetal consequences in the maternity ward of a general tertiary hospital.

\section{MATERIALS AND METHODS}

This is a descriptive study from the tertiary hospital Azevedo Lima maternity ward, in the City of Niterói, Rio de Janeiro, with a capacity for about 3.000 births/year.

Source of data and patients: Dengue/DHF is a disease reported by a surveillance program tem. The review of the Data Base included the cases from January 1st to December 30th, 2002, for pregnant women with suspected dengue fever. We adopted the WHO classification and case definitions to classify the patients for DF, DHF or DSS.

Screening of cases: All laboratory-confirmed cases during the period were included. We collected the demographic data from each patient and recorded the maternal and fetal progress as well as the outcome from both. The evaluation involved the time lapse from symptom onset to birth date, pregnancy age on the first day of the disease, clinical findings, delivery type, pleural effusion, platelet et $<100.000$ and increased liver enzymes, whenever present (Table 1). Pregnancy age at the time of the birth, newborn weight, clinical findings during the first week of life and newborn outcome are displayed in Table 2. Three placentas were analyzed.

Diagnosis: The laboratorial diagnosis was based on sera, both mother and newborn, for the detection of both dengue IgM antibodies (PanBio, Australia) and the viral RNA via RT-PCR ${ }^{[16]}$. A total of 3 placenta samples were available. The cases were considered positive upon the detection of a dengue specific IgM, viral RNA via RTPCR or the evidence of the virus antigen in placenta tissue samples through immunohistochemistry.

\section{RESULTS}

Our cohort consisted of 13 hospitalized women, with laboratory confirmed dengue (Table 1), 9 of which classified as dengue fever, 3 hemorrhagic dengue and 1 dengue shock syndrome.The most common warning signs were severe abdominal pain (6) followed by dyspnea (2). The average age of the pregnant women was 24 years old and the average time delay from infection to delivery was 18.3 days with a SD of 29.7 days (1-85 days).

Among the pregnant women who successfully gave normal (9 month) birth, the average period from symptom onset until birth was 36 days, with a SD of 44,4 (1-85). A different scenario was evident among the pregnant women who evolved to premature birth, where the average was 5.8 days, with a SD of $1.2(5-8)$.

In our cases, 1 patient infected in her first trimester of pregnancy and another in the second trimester evolved to premature birth. From the 11 patients, infected during their third trimester, 6 beared prematurely. Five births were via vagina, 7 via $\mathrm{C}$ section and there was 1 spontaneous abortion. The $\mathrm{C}$ sections were due to obstetric indication, as a consequence of acute fetal suffering (4) $57 \%$.

Clinical findings: The most frequent disorders were fever (10), headache (8), myalgia (8), premature birth (7), prostration (6) and olygodramnios (6). Four women were admitted to the ICU because of PIH and/or ARDS, 2 of which dying from ARDS and presenting extra-fluid in the abdominal cavity as a common factor. Ten patients produced some hemorrhagic manifestation, the most frequent being vaginal bleeding (5), digestive tract hemorrhage (3) and petechie (3). The two pregnant women who died exhibited dyspnea, ARDS, generalized edema as well as premature birth and 1 developed seizures (Table 1).

Laboratorial findings: All 13 women had a platelet count, 10 with thrombocytopenia $(<100.000)$ and 8 with hemorrhagic manifestations. Of the 3 without thrombocytopenia, 2 presented some hemorrhagic disorder. Seven underwent liver function testing, 4 exhibiting enzymatic alterations.

Fetus and newborn (Table 1 and 2).

The average pregnancy age was $33 \mathrm{~W}$ and 1 day. Four newborns were term-births, without alterations during hospitalization, receiving discharge at $48 \mathrm{~h}$ of life, with outpatient follow up until the 15th day of life. The average birth weight was $2334 \mathrm{~g}$. Seven out of 13 $(53 \%)$ were premature, which was the main clinical aspect. Other clinical signs included, early breathing discomfort, hypoactivity, vomiting, exanthema, jaundice and severe hyaline membrane disease. Of the seven newborns that had a platelet count, 3 had thrombocytopenia $(<100.000)$. None had hemorrhagic manifestations. Five newborns had low weight upon birth, however all displayed adequate weight considering their gestation age. One newborn failed to survive due to extreme premature birth (Table 2). 
Am. J. Infect. Dis., 5 (4): 288-293, 2009

Table 1: Maternal and fetal clinical characteristics and outcome

\begin{tabular}{|c|c|c|c|c|c|c|c|c|c|c|c|c|}
\hline Patient & Age & Time(d)* & $\begin{array}{l}\text { GA in } \\
\text { child } \\
\text { birth }\end{array}$ & $\begin{array}{l}\text { Bleeding } \\
\text { manifestations }\end{array}$ & $\begin{array}{l}\begin{array}{l}\text { Pleural } \\
\text { effusion/ } \\
\text { s ascites }\end{array} \\
\end{array}$ & $\begin{array}{c}\text { Platelet et } \\
<100.000\end{array}$ & $\begin{array}{l}\text { Liver } \\
\text { enzymes }\end{array}$ & $\begin{array}{l}\text { Others raised } \\
\text { clinical findings }\end{array}$ & $\begin{array}{l}\text { Admitted } \\
\text { to maternal }\end{array}$ & $\begin{array}{l}\text { Severity } \\
\text { ICU }\end{array}$ & $\begin{array}{l}\text { Mode of } \\
\text { delivery }\end{array}$ & $\begin{array}{l}\text { Maternal } \\
\text { outcome }\end{array}$ \\
\hline 1 & 29 & 8 & $39 w$ & no & $\mathrm{N}$ & $\mathrm{Y}$ & $\mathrm{N}$ & $\begin{array}{l}\text { Fever, prostation, } \\
\text { Myalgia, } \\
\text { headache, PIH }\end{array}$ & $\mathrm{N}$ & $\mathrm{DF}$ & $\mathrm{V}$ & $\mathrm{N}$ \\
\hline 2 & 19 & 5 & $34 \mathrm{w} 4 \mathrm{~d}$ & no & $\mathrm{N}$ & $\mathrm{Y}$ & NR & $\begin{array}{l}\text { Fever, headache, } \\
\text { myalgia, prostration, } \\
\text { oligohydramnios, } \\
\text { preterm delivery }\end{array}$ & $\mathrm{N}$ & $\mathrm{DF}$ & $\mathrm{V}$ & $\mathrm{N}$ \\
\hline 3 & 24 & 8 & $32 \mathrm{w} 6 \mathrm{~d}$ & $\begin{array}{l}\text { Petechie, } \\
\text { hematuria }\end{array}$ & $\mathrm{N}$ & $\mathrm{Y}$ & $\mathrm{Y}$ & $\begin{array}{l}\text { Fever, intense } \\
\text { abdominal pain, } \\
\text { headache, PIH, } \\
\text { swelling lower } \\
\text { limbs and face, } \\
\text { oligohydramnios, } \\
\text { preterm delivery }\end{array}$ & $\mathrm{Y}$ & DHF & $\mathrm{C}$ & $\mathrm{N}$ \\
\hline 4 & 24 & 6 & $35 \mathrm{w}$ & $\begin{array}{l}\text { Haematemesis, } \\
\text { vaginal bleedin }\end{array}$ & & $\mathrm{Y}$ & $\mathrm{N}$ & $\begin{array}{l}\text { Fever, intense } \\
\text { abdominal pain, } \\
\text { headache, myalgia, } \\
\text { arthargia, prostration, } \\
\text { dyspnea, myocarditis, } \\
\text { PDP, preterm delivery }\end{array}$ & $\mathrm{N}$ & $\mathrm{DF}$ & $\mathrm{C}$ & $\mathrm{N}$ \\
\hline 5 & 23 & 6 & $30 \mathrm{w} 2 \mathrm{~d}$ & $\begin{array}{l}\text { Petechie, } \\
\text { vaginal bleedin }\end{array}$ & ing & $\mathrm{Y}$ & NR & $\begin{array}{l}\text { Fever, headache, } \\
\text { myalgia, arthralgia, } \\
\text { pruritus,rash, prostation, } \\
\text { PIH, oligohydramnios, } \\
\text { PDP, preterm delivery }\end{array}$ & $\mathrm{Y}$ & $\mathrm{DF}$ & C & $\mathrm{N}$ \\
\hline 6 & 28 & 1 & $40 w 3 d$ & $\begin{array}{l}\text { Gastrointestinal } \\
\text { bleeding }\end{array}$ & i $\mathrm{N}$ & $\mathrm{N}$ & $\mathrm{N}$ & Rash & $\mathrm{N}$ & DF & $\mathrm{C}$ & $\mathrm{N}$ \\
\hline 7 & 29 & 5 & $35 \mathrm{w}$ & $\begin{array}{l}\text { Petechie, } \\
\text { vaginal } \\
\text { bledding, } \\
\text { hematuria }\end{array}$ & $\mathrm{N}$ & $\mathrm{Y}$ & NR & $\begin{array}{l}\text { Fever, myalgia, } \\
\text { rash, headache, } \\
\text { pruritus, preterm } \\
\text { delivery }\end{array}$ & $\mathrm{N}$ & DHF & $\mathrm{V}$ & $\mathrm{N}$ \\
\hline 8 & 16 & 4 & $10 w 4 d$ & $\begin{array}{l}\text { Gengivorragia, } \\
\text { vaginal bleddin }\end{array}$ & & $\mathrm{Y}$ & NR & $\begin{array}{l}\text { Fever, headache, } \\
\text { prostration, } \\
\text { arthralgia, myalgia, } \\
\text { intense abdominal } \\
\text { pain, abortion }\end{array}$ & $\mathrm{N}$ & $\mathrm{DF}$ & $\mathrm{V}$ & $\mathrm{N}$ \\
\hline 9 & 16 & 5 & $8 w$ & $\begin{array}{l}\text { Pulmonary } \\
\text { Hemorrhage, }\end{array}$ & $\mathrm{Y}$ & $\mathrm{Y}$ & $\mathrm{Y}$ & $\begin{array}{l}\text { Seizurs, } \\
\text { oligohydramnios, } \\
\text { PIH, dyspnea, } \\
\text { ARDS, generalized } \\
\text { edema, preterm } \\
\text { delivery }\end{array}$ & $\mathrm{Y}$ & DCS & C & Death \\
\hline 10 & 23 & 84 & $38 w 4 d$ & no & $\mathrm{N}$ & $\mathrm{N}$ & $\mathrm{Y}$ & $\begin{array}{l}\text { Fever, prostation, } \\
\text { myalgia, jaundice }\end{array}$ & $\mathrm{N}$ & DF & $\mathrm{V}$ & $\mathrm{N}$ \\
\hline 11 & 27 & 85 & $38 \mathrm{w} 6 \mathrm{~d}$ & epistaxsis & $\mathrm{N}$ & $\mathrm{N}$ & NR & $\begin{array}{l}\text { Fever, headache, } \\
\text { rash, myalgia, } \\
\text { arthralgia, pruritus, } \\
\text { intense abdominal } \\
\text { pain, hepatomegaly } \\
\text { painful, postural } \\
\text { hipotension, } \\
\text { oligohydramnios }\end{array}$ & $\mathrm{N}$ & DF & C & $\mathrm{N}$ \\
\hline 12 & 18 & 2 & $40 w 4 d$ & $\begin{array}{l}\text { Vaginal } \\
\text { bleeding }\end{array}$ & $\mathrm{N}$ & $\mathrm{Y}$ & NR & $\begin{array}{l}\text { Intense abdominal } \\
\text { pain, oligohydramnios }\end{array}$ & $\mathrm{N}$ & $\mathrm{DF}$ & $\mathrm{V}$ & $\mathrm{N}$ \\
\hline 13 & 37 & 19 & $26 \mathrm{w}$ & $\begin{array}{l}\text { Epistaxsis, } \\
\text { Haematmesis }\end{array}$ & $\mathrm{Y}$ & $\mathrm{Y}$ & $\mathrm{Y}$ & $\begin{array}{l}\text { Fever, hepatomegaly } \\
\text { painful, dyspnea, } \\
\text { ARDS, jaundice, } \\
\text { generalized edema, } \\
\text { liver abscess, preterm } \\
\text { delivery }\end{array}$ & $\mathrm{Y}$ & DHF & C & Death \\
\hline
\end{tabular}

*: Time elapsed between the first day of illness and childbirth. GA: Gestacional Age; N: No; Y: Yes; PDP: Premature Detachment of Placenta; DF: Dengue Fever; DHF: Dengue Haemorrhagic Fever; DCS: Dengue Shock Syndrome; C: Caesarean section; V: Vaginal delivery

Anathomopathological results: The results of the three cases examined, the macroscopic exam of the placenta disclosed, in one case, a fetal face lined with an opalescent ovular membrane and in the other two, a 
Am. J. Infect. Dis., 5 (4): 288-293, 2009

Table 2: Clinical characteristics and outcome in newborn

\begin{tabular}{|c|c|c|c|c|c|c|c|}
\hline $\mathrm{N}$ & Date of birth & Time* (by days) & $\begin{array}{l}\text { GE at birth } \\
\text { (weeks) }\end{array}$ & $\begin{array}{l}\text { Birth } \\
\text { weight }(\mathrm{g})\end{array}$ & $\begin{array}{l}\text { Clinical } \\
\text { findings }\end{array}$ & $\begin{array}{l}\text { Platelet et } \\
<100000\end{array}$ & $\begin{array}{l}\text { Fetal and } \\
\text { newborn outcome }\end{array}$ \\
\hline 1 & 1.27 & 8 & $39 \mathrm{w}$ & 2560 & Asymptomatic & NA & Discharge \\
\hline 2 & 2.03 & 5 & $34 \mathrm{w} 4 \mathrm{~d}$ & 2020 & $\begin{array}{l}\text { Early respirarory distress, } \\
\text { hipoactivity, vomiting, } \\
\text { prematurity }\end{array}$ & Yes & Discharge \\
\hline 3 & 2.06 & 8 & $32 \mathrm{w} 6 \mathrm{~d}$ & 1830 & Prematurity & No & Discharge \\
\hline 4 & 2.16 & 6 & $35 w$ & 1900 & Prematurity & No & Discharge \\
\hline 5 & 2.20 & 6 & $30 \mathrm{w} 2 \mathrm{~d}$ & 1520 & $\begin{array}{l}\text { Extreme prematurity, } \\
\text { early respirarory distress, } \\
\text { bilateral cracking rales }\end{array}$ & No & Discharge \\
\hline 6 & 3.13 & 0 & $40 w 3 d$ & 3200 & Asymptomatic & NA & Discharge \\
\hline 7 & 3.28 & 5 & $35 w$ & 2590 & Prematurity, jaundice & Yes & Discharge \\
\hline 9 & 4.23 & 5 & $28 \mathrm{w} 5 \mathrm{~d}$ & 1180 & Prematurity & NA & Fetal death \\
\hline 10 & 5.30 & 84 & $38 w 4 d$ & 2875 & Asymptomatic & NA & Discharge \\
\hline 11 & 6.02 & 85 & $38 \mathrm{w} 6 \mathrm{~d}$ & 3295 & Asymptomatic & NA & Discharge \\
\hline 12 & 7.21 & 2 & $40 \mathrm{~s} 4 \mathrm{~d}$ & 3310 & Asymptomatic & No & Discharge \\
\hline 13 & 8.04 & 19 & $26 w$ & 575 & $\begin{array}{l}\text { Extreme prematurity, } \\
\text { severe hyaline membrane } \\
\text { disease, neonatal sepsis }\end{array}$ & Yes & Death \\
\hline
\end{tabular}

*: Time elapsed between the first day of illness and childbirth; **: One abortion occurred at age of 10w 4d (case 8); NA: Not Available

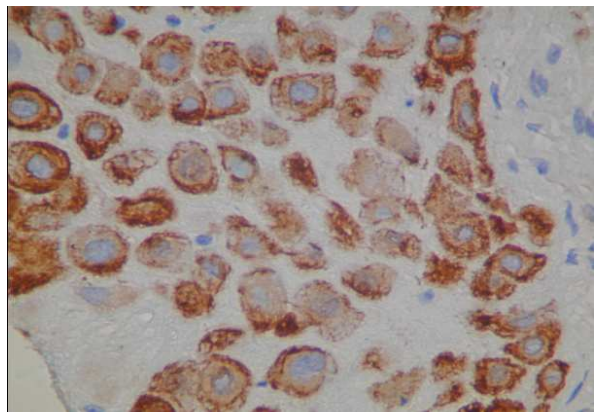

Fig. 1:Multifocal immune reaction in syncytiotrophoblast and cytotrophoblast cells (case 9)

brilliant, smooth and transparent membrane. The chorionic vessels, in two, presented reduced caliber and a normal caliber in the other. In 2 cases, there was faint tessellation, while in the third it was evident in the other. The maternal face was normal in two cases, in the third presenting an area of $5.5 \times 4 \mathrm{~cm}$, of central location, with a strongly adhered clot.

The microscopic study revealed, in two cases, a mononuclear inflammatory afflux at the level of the decidua, the chorial villosity exhibiting an edema of the villous stroma and lymphoplasmocytic inflammatory afflux in all 3 cases. One of the cases presented inflammatory fibrinae cells, poli and mononuclear, in the intrevillositis space which reached the villosity lining epithelium in areas of the placenta. The umbilical cord displayed, in one case, a mononuclear inflammatory afflux in the permeation mesenquimal tissue to the funicular vessils.
Immunohistochemistry results: The immunohistochemical study for Dengue using the technique of streptavidin-biotin and polyclonal antibodies to Dengue imunoreaction accused stromal cells in tissue, with a granular pattern in the cytoplasm (case 2) as well as in syncytiotrophoblast and cytotrophoblast cells of the immune reaction with multifocal (case 9) Fig. 1.

\section{DISCUSSION}

This study presents clinical and laboratory findings of the first cohort of patients with serologically confirmed dengue infection during pregnancy reported in Brazil, to date. The two pregnant women who died of DHF and shock syndrome were the only ones with fluid leakage. Despite the presence of severe abdominal pain in most of the patients (46\%), only two were associated to the capillary leakage syndrome.

Intense abdominal pain in pregnant women might represent a premature sign of a serious disorder and must be taken into account. However, in this group, this indication might have been mistakenly confused with other symptoms, such as uterus contraction or labor.

The average age of the pregnant women is in accordance with the proportion of the live newborns, per mothers' age, with respect to the age of the mother for the State of Estado do Rio de Janeiro (28.61\%, for ages between 20 and 24 years). This is the age bracket with the highest proportion ${ }^{[17]}$.

Fluid leakage (haemoconcetration, pleural or abdominal effusion) and hemorrhagic manifestations are characteristics of DHF. Although 10 of the 13 women presented some hemorrhagic affliction, only 
3 met the criteria for DHF. Six patients received the classification of "complicated DF" as there was bleeding without further signs of DHF, such as thrombocytopenia (absent in two of them), haemoconcetration (not present at all) or the clinical syndrome of plasma leakage (absent in the majority). It is not clear whether or not hemorrhagic is necessarily associated with thrombocytopenia, as two patients did present it without laboratorial abnormalities in the platelet count. In addition, the haemodilution linked to normal pregnancy can mask the classical criteria of haemoconcetration in DHF. Carles ${ }^{[4]}$ described 22 pregnancies with dengue, 10 with thrombocytopenia, in which there was no hemorrhagic dengue.

Thus, there ought to be a high level of suspicion to detect fluid leakage in pregnant patients with dengue. We recommend that every pregnant woman, bearing the suspicion of dengue infection, undergo abdominal and thorax US to confirm the presence of plasma leakage, since it might be an early and unique only sign of severity in pregnant infected women.

The two pregnant women who died of DHF and shock syndrome were the only ones who presented signs of fluid leakage associated with ARDS, similar to that described by $\operatorname{Lum}^{[18]}$. Tagore et al. ${ }^{[19]}$ related a hemorrhagic dengue fever case complicated by eclampsia in pregnancy, similar to one of our patients.

In our cases, C-sections represented $71,4 \%$ (5) of the births based on the main indication of fetal suffering. Moreover, the number of premature births was above maternity average. As dengue clinical symptoms appeared approaching delivery premature birth risk increased, suggesting a direct implication of maternal viremia in preterm delivery. The total number of live newborns for 2002 was 2161 with $18 \%$ (618) premature births.

All 4 patients admitted to the ICU beared prematurely, of which 3 presented fever, $\mathrm{PIH}$ and olygodramnios and the 2 patients who failed to survive exhibited pleural effusion and ascites, the most important signs in severity differentiation. There was no correlation between abdominal pain and severity, despite the assumed association. About 15 Whether olygodramnios is a result of DENV infection or PIH has not yet been established.

It is not clear whether or not the hemorrhagic manifestations were related to the thrombocytopenia, as some patients were affected without laboratorial abnormalities in platelet count.

Liver enzyme results were available in only seven patients, of which $100 \%$ of those with DHF and $25 \%$ with DF presented elevated liver enzymes, a pattern similar to other reports. Though the liver is not the primary target organ of this disease, there are cases of hepatic histopathology having been detected in patients with Dengue Hemorrhagic Fever (DHF) and Dengue Shock Syndrome (DSS). The viral disease is selflimited, but hepatic insufficiency can occur in some patients $^{[4-7]}$.

The average gestation age upon birth, $33 \mathrm{~W}$ and 1 day, indicates the association between DENV infection and premature birth. Although an increase in the frequency of birth prematurity (53\%) among DENV infected mothers was noted and consequently a low birth weight, no newborns presented signs of intra uterine growth retardation, nor were there any fetal malformations.

It was not possible to associate neo-death to maternal dengue infection ${ }^{[5,20]}$, as the complications of the extreme prematurity, such as the severe hyaline membrane and the neonatal sepsis, might have been responsible for the death. The perinatal transmission of DENV is rare in the literature, however we have confirmed it in three cases (one newborn serology and two immunochemistry). We think that it might be more evident, if it were researched in a systematic modality.

Considering the importance of dengue virus infection around the world, there have been too few studies regarding the effects of this disease in the newborn and the wide spectrum of manifestations and severity involving the maternity scenario. The evaluation of dengue in pregnant women might aid in a better clinical approach for the pregnant woman and follow up of the newborn in the neonatal period.

\section{CONCLUSION}

Dengue virus infection in pregnancy increases premature birth risk, especially if the infection occurs in the last quarter of pregnancy.

\section{ACKNOWLEDGEMENT}

We would like to acknowledge Dr. Carlos Malvone and Dr. Heleonora Orvelin for their indispensable assistance with protocols and hospital procedures.

English review and revision by Mitchell Raymond Lishon, Native of Chicago, Illinois, USA-UCLA 1969.

\section{REFERENCES}

1. Guzman, M.G. and G. Kouri, 2001. Dengue: An update. Lancet, 22: 33-42.

2. Schatzmayr, H.C., 2001. Emerging and reemerging viral diseases. Cad Saúde Pública, 17: 209-213. http://www.scielo.br/pdf/csp/v17s0/3898.pdf 
3. Carles, G., A. Talarmin, C. Peneau and M. Bertsch, 2000. Dengue fever and pregnancy. A study of 38 cases in French Guyana. J. Gynecol. Obstet. Biol. Reprod. 29: 758-762. http://cat.inist.fr/?aModele $=$ afficheN\&cpsidt $=8259$ 16

4. Carles, G., H. Peiffer and A. Talarmin, 1999. Effects of dengue fever during pregnancy in French Guiana. Clin. Infect. Dis., 128: 637-640.

5. Chye, J.K. et al., 1997. Vertical transmisión of dengue. Clin. Infect. Dis., 25: 1374-1377. http://www.ncbi.nlm.nih.gov/pubmed/10194092

6. Taithumyanon, P., U. Thisyakorn, J. Deerojnawong and B.L. Innis, 1994. Dengue infection complicated by severe hemorrhage and vertical transmission in a parturient woman. Clin. Infect. Dis., $\quad$ 18: 248-249. http://direct.bl.uk/bld/PlaceOrder.do?UIN=013723 $357 \&$ ETOC $=$ EN $\&$ from $=$ searchengine

7. Figueiredo, L.T.M., R.H. Carlucci and G. Duarte, 1994. Prospective study with infants whose mothers had dengue during pregnancy. Rev. Inst. Med. Trop. Sao Paulo, 36: 417-421. http://www.ncbi.nlm.nih.gov/pubmed/7569608

8. Malhotra, N., C. Chanana and S. Kumar, 2006. Dengue infection in pregnancy. IJGO., 94: 131-132. http://portal.saude.gov.br/portal/arquivos/kitdengue 2/aspectosclinicos/textos/dengue_pregnancy.pdf

9. Tan, P.C., G. Rajasingam, S. Devi and S.Z. Omar, 2008. Dengue infection in pregnancy. Prevalence, vertical transmission and pregnancy outcome. Abstet. Gynecol., 111: 1111-1117. http://www.ncbi.nlm.nih.gov/pubmed/18448743

10. Kerdpanich, A. et al., 2001. Perinatal dengue infection. Southeast Asian J. Trop. Med. Public Health, 32: 488-493. http://direct.bl.uk/bld/PlaceOrder.do?UIN=107537 $582 \&$ ETOC $=$ RN \& from $=$ searchengine

11. Ahmed, S., 2003. Vertical transmission of dengue: First case report from Bangladesh. Southeast Asian J. Trop. Med. Public Health, 34: 800-803. http://www.dengue.lcc.ufmg.br/dengue_cd/files/gr avidez/Verticall.pdf
12. Janjindamai, W. and P. Pruekprasert, 2003. Perinatal dengue infection: A case report and review of literature. Southeast Asian J. Trop. Med. Public Health, 34: 793-796. http://cat.inist.fr/?aModele $=$ afficheN\&cpsidt=1569 4340

13. Witayathawornwong, P., 2003. Parturient and perinatal dengue hemorragic fever. Southeast Asian J. Trop. Med. Public Health, 34: 797-799. http://cat.inist.fr $/$ ?aModele $=$ afficheN\&cpsidt $=1569$ 4341

14. Poli, L., E. Chungue, O. Soulignac, P. Gestas, P. Kuo and M. Papouin-Rauzy, 1991. Maternofetal dengue. Apropos of 5 cases observed during the epidemic in Tahiti (1989). Bull. Soc. Pathol. Exot., 84: 513-521. http://www.ncbi.nlm.nih.gov/pubmed/1819401

15. Nogueira, R.M.R., H.G. Schatzmayr, A.M.B. Filippis, F.B. Santos and R.V. Cunha et al., 2005. Dengue virus type 3, Brazil. Emerg. Infect. Dis., 11: 1376-1381.

16. Lanciotti, R.S., C.H. Calisher, D.J. Gubler, G.J. Chang and V. Vorndam, 1992. Rapid detection and typing of dengue viruses from clinical samples by using reverse transcriptase-polymerase chain reaction. J. Clin. Microbiol., 30: 545-551. http://www.ncbi.nlm.nih.gov/pubmed/1372617

17. IDB 2007. Indicators and basic data-brasil. http://tabnet.datasus.gov.br/cgl/idb2007/matriz.htm

18. Lum, L.C.S., M.K. Thong, Y.K. Chea and A.K. Lam, 1995. Dengue-associated adult respiratory distress syndrome. Ann. Trop. Paediat., 15: 335-339. http://cat.inist.fr/?aModele $=$ afficheN\&cpsidt $=2941$ 421

19. Tagore, S., C.F. Yim and K. Kwek, 2007. Dengue haemorrhagic fever complicated by eclampsia in pregnancy. Singapore Med. J., 48: e281-e283. http://www.dengue.lcc.ufmg.br/dengue_cd/files/gr avidez/4810cr8.pdf

20. Choudhry, S.P., R.K. Gupta and J. Kishan, 2004. Dengue shock syndrome in new born-A case series. Indian Pediat., 41: 397-399. http://www.ncbi.nlm.nih.gov/pubmed/15123872 